\title{
From an efficient to a viable international financial market
}

\section{Chen Ping}

\section{Introduction}

This ongoing grand crisis originated in the United States, then transmogrified into an international crisis. It represents a natural experiment. The positive side of this crisis is its fundamental lesson. It is not a theoretical debate confined to ivory towers, but a historical event that has destroyed social confidence in the mainstream equilibrium theory of the so-called efficient market. This has accelerated the rise of the non-linear evolutionary theory of the viable market. Four observations reveal where the equilibrium theory of asset pricing and business cycles went wrong: 1) exchange rate resonance driven by US business cycles; 2) the meso-foundation of macrofluctuations; 3) the endogenous nature of persistent cycles in financial macro-indexes; and 4) the trend of collapse and higher moment risk in the derivative market. The new perspective of non-linear population dynamics in continuous time provides a better alternative to existing rational-actor/linear models of finance, not only for understanding the cause of the present situation, but to inform efforts related to redesign and reform. The systematic failure in the mortgage security market, unprecedented concentration in the international financial market, and unfettered speculation in the commodity and currency markets have all contributed to the current disaster. A new international financial order can be achieved if a robust and workable international antitrust law can be enacted and a Tobin tax on foreign exchange transactions can be established through global efforts. An overhaul of financial theory is needed to develop a viable market for sustainable economies. 


\section{Empirical observations and policy implications: econometric illusion in the efficient market and an alternative strategy for a viable market}

Our empirical analysis of business cycles draws on tools developed by the new science of complexity and non-linear dynamics, which were applied to US economic time series (Chen 1988, 1996a, 1996b, 2002, 2006, 2007). The policy recommendations were reached based on alternative scenarios tested under the rubric of non-linear evolutionary dynamics in finance and economics (Chen 2005, 2008). The debate begins by examining exchange rate co-movements and the nature of business cycles, before proceeding to examine the misleading role of linear models in asset pricing.

\section{Exchange rate resonance among major currencies and a Tobin tax to discourage short-term speculation}

What was the source of the US financial crisis? US Federal Reserve Chairman, Ben Bernanke, has attributed it to over-consumption in the United States and over-saving in China, while Treasury Secretary, Tim Geithner, has blamed China's exchange rate policy. Is there any empirical evidence in the conventional arena predicting the unstable nature of the international financial market? Econometric tests based on regression analysis cannot reach a conclusion since their results depend on untenable assumptions about underlying dynamic structures. In contrast, our observations are based on non-parametric analysis of the currency depreciation pressure index (CDP), which is constructed in terms of covered interest rate parity (IRP). We can consider CDP as a disequilibrium measurement of the degree of deviation from IRP (Jia and Chen 2009). We plot major currency trajectories over time (Figure 3.1), including the euro, the Japanese yen, British pound sterling and the Chinese renminbi. Equilibrium theory asserts that an efficient market should be characterised by the absence of arbitrage opportunity. If equilibrium theory is valid in the international financial market, we should see horizontal lines in time, not wave-like resonance. Its relation with monetary instruments is shown in Figure 3.2. 
Figure 3.1 Currency depreciation pressure indexes for the euro, yen, pound sterling and renminbi, January 1999 - February 1999

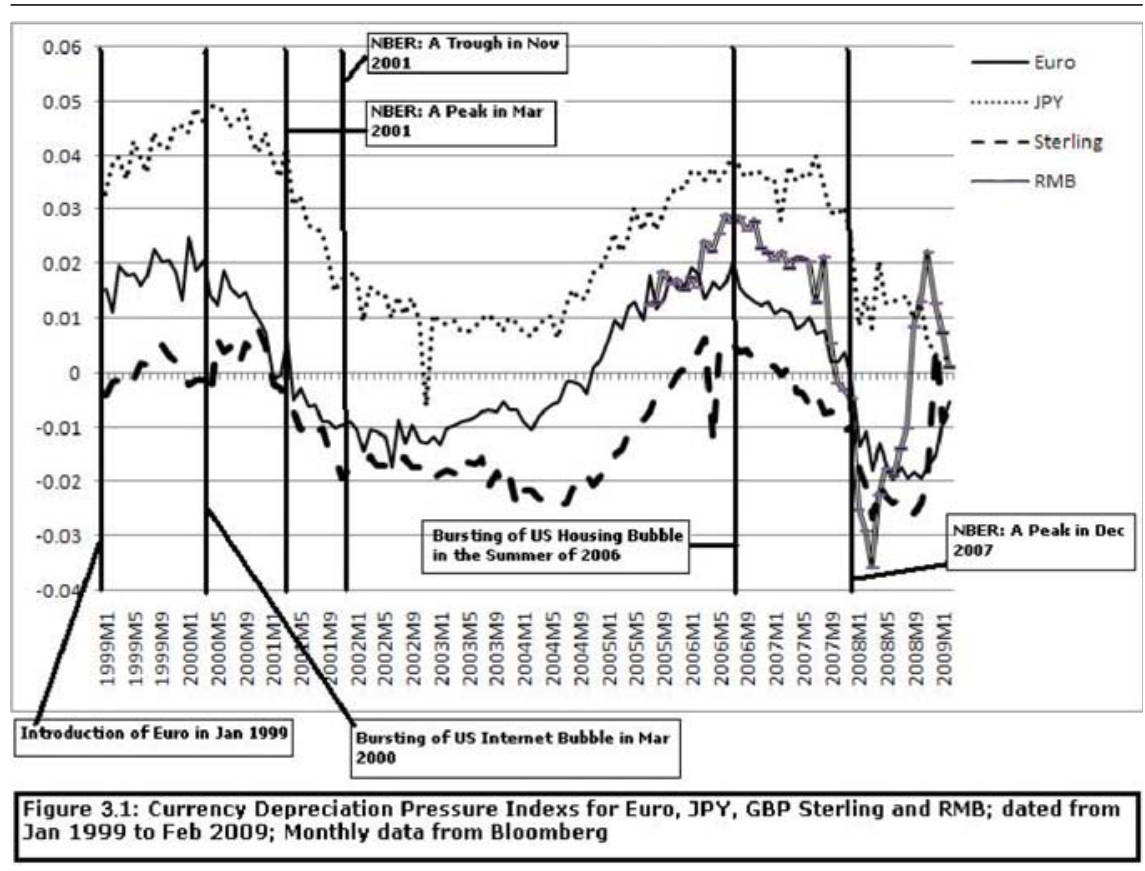

Source: Monthly data from Bloomberg.com.

The wave-like resonance patterns among the major-economy exchange rates in Figure 3.1 have a close correlation with the US business cycles as defined by the National Bureau of Economic Research (NBER). The vertical axis is the CDP measure of depreciation pressure. 
Figure 3.2 Time trajectories of various US interest rates

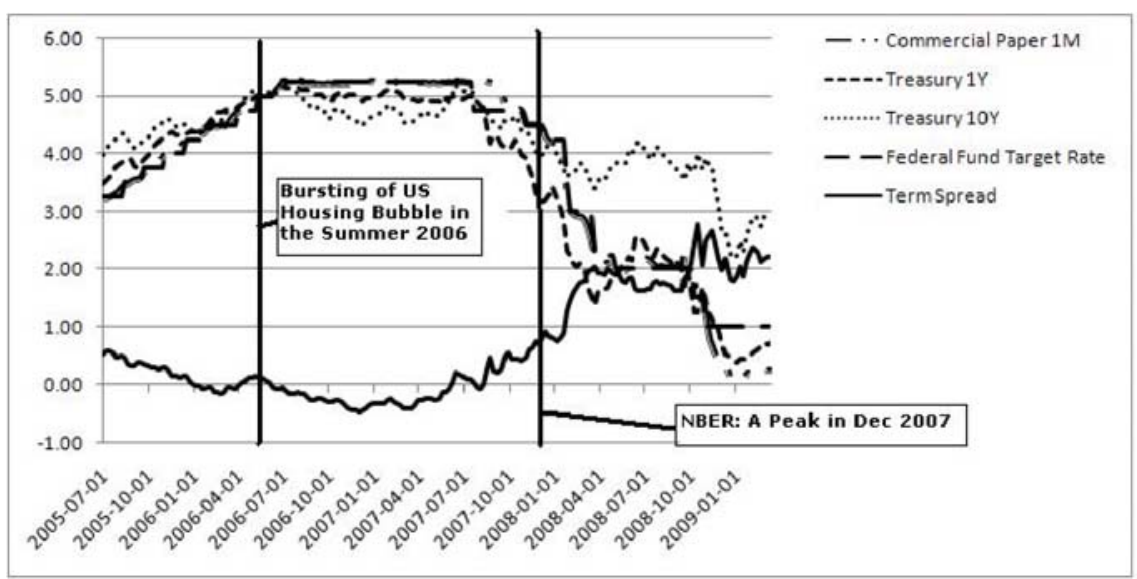

Figure 3 depicts various of US Interest Rates, including 1-month Commercial paper rate, 1-year Treasury Bill rate, 10-year Treasury Bill rate, Federal Fund Target Rate as well as term spread. We use weekly data, downloaded from Federal Reserve at St. Luis!

Source: Weekly data from Federal Reserve Bank at St Louis.

From Figure 3.2, we can see clearly that only long-term interest rates signal the boom and bust in business cycles.

Based on the above observations, we see no evidence of an equilibriumefficient market encapsulated in risk-free arbitrage in the currency market. Detailed studies show little correlation between exchange rate resonance and other fundamental variables in the US economy, such as trade and budget deficits. On the contrary, there is strong evidence of US power in the international market, since the exchange rate resonance is clearly driven by US business cycles. This implies that the US economy is the dominant market for international capital flow - which it is. No other currencies have countervailing power against the tide of the US economy. This implication is important for designing the new international financial order. Even if the US economy declines significantly, there is no candidate to replace the US dollar as the world's reserve currency in the near future.

\section{Endogenous nature of US persistent business cycles and a new perspective on risk management}

If the exchange rates of major countries are driven by US business cycles, the next question must be about the nature of business cycles. Are they generated by external shocks (Frisch 1933, Lucas 1972) or by internal instability (Schumpeter 1939; Chen 1988, 1996a)? This issue is 
essential, since all textbook investment strategies related to diversification and hedging are based on a simple assumption that an efficient market is characterised by a random walk or Brownian motion, without countenancing the possibility of non-linear deterministic patterns such as persistent cycles and chaos (Friedman 1953; Fama 1970, 1991; Black and Scholes 1973). The application of a new technique of time-frequency analysis based on WGQ (Wigner-Gabor-Qian) transformation in timefrequency space has led to the development of a powerful tool for nonstationary time-series analysis, which can replace these conventional models (Chen 1996a, 2005, 2008). Solid evidence of endogenous persistent cycles is shown in Figure 3.3, while the equilibrium illusion of white noise is simply created by the first-difference (FD) filter (Figure 3.4), which is a high-frequency noise amplifier by nature (Chen 2008).

\section{Figure 3.3 Endogenous nature of S\&P 500 index movements}

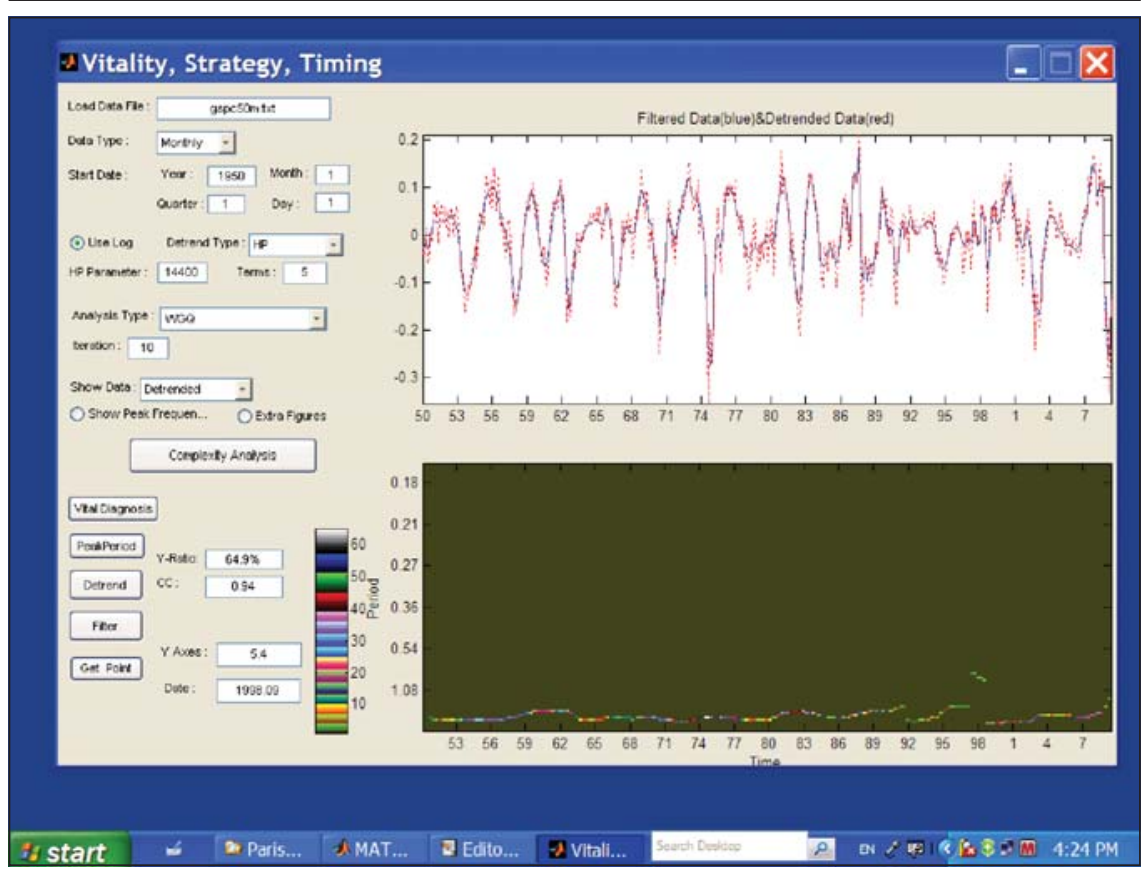

As shown in Figure 3.3, deterministic cycles can explain 64.9 per cent of variance from HP-detrended cycles filtered by WGQ transformation in time-frequency space. The cross-correlation with original cycles is 0.94. We found these persistant cycles can be explained by color chaos. Color means that its intrinsic period is about 4 to 5 years. Color chaos 
is deterministic chaos in continous-time. Its correlation dimension is 2.5 (Chen 2005). Color chaos can be considered as the nonlinear model of Schumpeter's biological clock, a better alternative model of random walk or white noise in equilibrium theory of business cycles.

\section{Figure 3.4. The frequency response function for the FD filter}

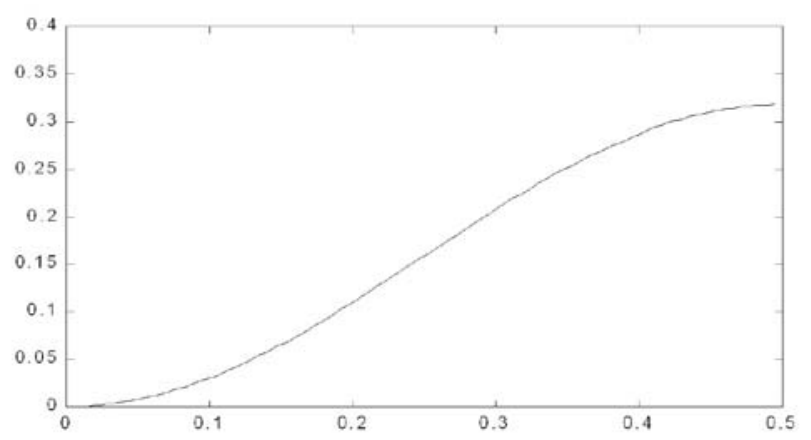

Here, $X(t)=F D[S(t)]=S(t+1)-S(t)$; the horizontal axis is the frequency range from zero to 0.5. Clearly, this is a whitening device, which suppresses low-frequency signals in business-cycle range but amplifies high-frequency noise for creating an equilibrium illusion of an 'efficient market' dominated by white noise.

What can be learnt from these observations? First, white noise plays only a non-dominant role in the financial market. For example, the white noise component represents only about 30 per cent of the variance of the HP-filtered cycles. Second, the equilibrium theory of efficient markets provides a distorted image of reality. We find that the intrinsic frequency of stock market indexes is remarkably stable about the business-cycle frequency, while the price level varies erratically. Therefore, price does not contain all the information about market movements. Market trends, cyclical periods and correlation phases are more essential information than the price level for business decision making and macro-management. Third, the equilibrium theory of asset pricing offers a misleading recipe for risk management. A diversification strategy works only if market movements have no systematic trends and persistent cycles and all players make independent rational decisions without correlated actions. If business cycles play a leading role in market movements, cash-flow management should be the key factor in risk management - a fact that is often missing from traditional asset-pricing theory. Investors do not just make a simple choice between stocks and bonds. Cash can become king when uncertainty is pervasive. That is why securitisation is not capable of 
preventing crises such as the sub-prime debacle. On the contrary, complex tools of derivative trading amplify market resonance under the guidance of equilibrium finance theory.

\section{The meso-foundation of macro-fluctuations and competition policy in the global economy}

Lucas (1972) made a strong claim that business cycles could be explained by an equilibrium (rational expectations) mechanism of workers' choices between work and leisure. His micro-foundations theory has, however, been rejected by empirical observations based on the principle of large numbers (Chen 2002). It was Schrödinger (1948), the founder of quantum mechanics and quantum biology, who found a salient relationship between the number of micro-elements and the variability of aggregate fluctuations.

\section{Equation 3.1}

Market variability $(\mathrm{MV})=\frac{\operatorname{STD}\left(S_{N}\right)}{\operatorname{Mean}\left(S_{N}\right)} \approx \frac{1}{\sqrt{N}}$

The implication of Equation 3.1 is very clear. The more micro-elements involved, the less will be the aggregate fluctuation. This is the principle of large numbers. This relation holds not only for static aggregation, but for some dynamic systems such as the population dynamics of the birthdeath process (Chen 2002). Empirically speaking, since we can measure market variability (MV) from aggregate indexes, we can also infer the effective cluster number ( $\mathrm{CN}), \mathrm{N}$, at the micro-level. Therefore, we have a powerful tool to identify the source of aggregate fluctuations - if there is an explanation for micro-foundations (the structural level of households and firms) or an explanation for meso-foundations (the structural level of financial intermediates and industrial organisation in the form of clusters). The empirical results are shown in Table 3.1. 


\section{Table 3.1 Market variability and effective number for various} aggregate indexes

\begin{tabular}{l|c|c}
\hline Item & MV (\%) & CN \\
\hline Real personal consumption & 0.15 & 800000 \\
\hline Real GDP & 0.2 & 500000 \\
\hline Real private investment & 1.2 & 10000 \\
\hline Dow Jones Industrial (1928-2009) & 1.4 & 9000 \\
\hline S\&P 500 Index (1947-2009) & 1.6 & 5000 \\
\hline NASDAO (1971-2009) & 2.0 & 3000 \\
\hline Japan-US exchange rate (1971-2009) & 6.1 & 300 \\
\hline US-Euro exchange rate (1999-2009) & 4.9 & 400 \\
\hline Texas crude oil price (1978-2008) & 5.3 & 400 \\
\hline
\end{tabular}

Notes: For non-stationary time series, market variability is measured via the HP filter; the average is estimated from a moving time window in the range of the average length of business cycles, here is proxied at five years (Chen 2002).

Sources: US aggregate indexes and exchange rates are sourced from the Federal Reserve Bank of St Louis; stock indexes data are from <yahoo.finance >; the oil price index is from the US Energy Information Administration.

The number of households, corporations and public companies and their implied orders of market variation (MV) in 1980 are given in Table 3.2.

\section{Table 3.2 Numbers of households and firms in the United States, 1980}

\begin{tabular}{l|l|l|l}
\hline Micro-agents & Households & Corporations $^{\mathrm{a}}$ & Public companies \\
\hline $\mathrm{N}$ & 80700000 & 2900000 & 20000 \\
\hline MV (\%) & 0.01 & 0.1 & 0.7 \\
\hline
\end{tabular}

a Here, we count only those corporations with more than $\$ 100000$ in assets.

Source: The data are from the U.S. Bureau of Census.

From Tables 3.1 and 3.2, we can see that household fluctuations contribute only about 5 per cent of fluctuations in real gross domestic product (GDP) and less than 1 per cent in real investment; and small firms can contribute 50 per cent of fluctuations in real GDP or 8 per cent in real investment, while public companies can generate about 60 per cent of aggregate fluctuations in real investment. Clearly, there are very weak 'micro-foundations' but strong evidence of a 'meso-foundation' in macroeconomic fluctuations. The doctrine of 'too big to fail' might be true at the micro-level in the cases of external shocks, but it is not true at the macro-level in terms of the meso-macro relationship. This fallacy of composition still fools equilibrium economists in their representative model of macro behaviour. 
More surprisingly, the order of market variability in the oil and currency markets is much higher than real investment and the stock market, which indicates the ugly fact of financial concentration generated by giant financial corporations. This is the real root of this grand crisis!

Dan Gilligan, President of the Petroleum Marketers Association (PMA), has revealed that financial giants such as Morgan Stanley, Goldman Sachs, Barclays and JP Morgan was manipulating the oil price (Gilligan 2009They put hundreds of billions of dollars in the oil futures market, in addition to money invested by large institutional fund managers such as the California Pension Fund, the Harvard University Endowment, and other institutional investors. They started their speculation in 2000, when the US Congress deregulated the futures market, granting exemptions for complicated derivative investments called oil swaps, as well as electronic trading on private exchanges. Volatility in the price of oil increased dramatically. Later in the decade, within one year, the oil price rose from $\$ 67$ a barrel to $\$ 147$ a barrel, then collapsed back down to $\$ 45$. On one occasion, the oil price jumped $\$ 25$ in one day! Surprisingly, changes in oil demand and supply in this period were less than 5 per cent, while changes in the price of oil were larger than 100 per cent! From the middle of June to the end of November 2008, when a US congressional investigation started, about $\$ 70$ billion of speculative capital left the futures market. At that time, demand for oil dropped 5 per cent, but the price of oil dropped more than 75 per cent to $\$ 100$ a barrel. Gilligan estimated that about $60-70$ per cent of oil contracts in the futures market were controlled by speculative capital at the peak. In the past five years, hedge funds and global banks have poured capital into the oil market. Their 'investment' rose from $\$ 13$ billion to $\$ 300$ billion. Something must be done to stabilise commodity futures markets.

\section{Rethinking the theoretical foundation of trend collapse, higher moment risk and the financial crisis in the derivatives market}

In the 2008 financial crisis, credit default swaps (CDS) played an important role when the fall of Lehman Brothers generated a tremendous loss for AIG. We suspect that the oversimplified model of CDS options based on orthodox pricing theory played a significant role in ignoring underlying market instability.

An important discovery related to the principle of large numbers is the viable dynamics for sustainable markets. For stochastic dynamics with 
a growth trend, there exist stochastic models with the distinct feature of market variability (Chen 2002, 2005; Li 2002). Their results are quite enlightening. Random walks are damping, Brownian motion is explosive, but the birth-death process tends to a constant in the form of the principle of large numbers. The random walk and Brownian motion are representative agent models by nature. Only the birth-death process is a population model, which is capable in describing social interaction and collective action in behavioural finance.

It is possible to modify the option-pricing model based on the population model of the birth-death process in stock-price movements (Zeng and Chen 2008). For the representative agent model of geometric Brownian motion, the probability of stock-price movement can be described by a binomial tree (Cox et al. 1979). Credit default swap valuation is also based on a similar model (Duffie 1999). For our model in the birth-death process, stock-price changes can be understood by a trinomial tree: in addition to the probability of prices moving up and down, there is a chance of a stable price. This complexity might exhibit the so-called volatility smile (changing market volatility driven by irrational herd behaviour in financial market) observed in option prices. A more general model of evolution in probability distribution can be derived in terms of a master equation (Tang and Chen 2009). Based on empirical observation, transition probability can be described by a non-linear function; its solution can be approximated by expansion in terms of higher moments. If we consider only the first and second moment (i.e. mean and variance in portfolio theory), the solution will converge to that of the Black-Scholes model, in which an arbitrage-free portfolio can be constructed. If, however, we add the third and fourth moments, the model solution might produce complex patterns, such as a trend collapse and market crisis (Figures 3.5a and 3.5b). In other words, financial crisis can be understood as higher moment risk. 
Figure 3.5a Observed market crisis*

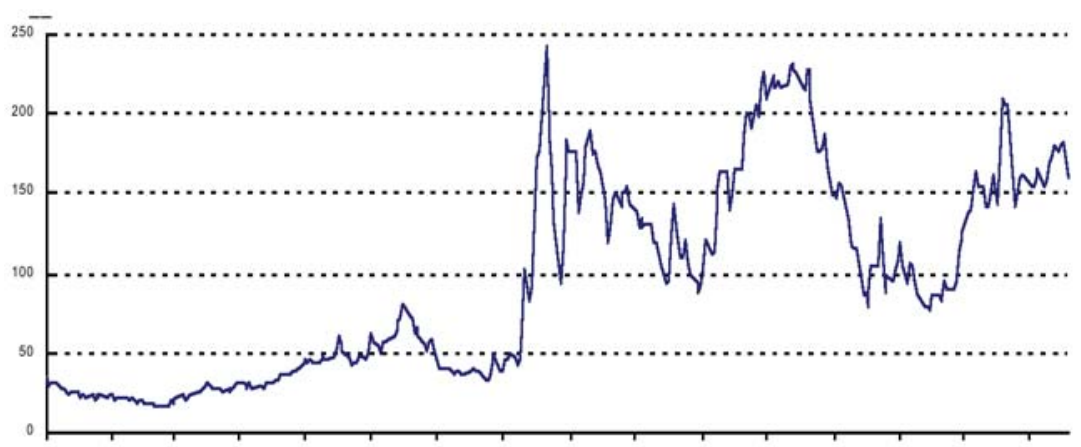

* The observed TED (three month interest rate spread between euro dollar LIBOR rate and US Treasury bill rate) series (January 2007 - April 2008).

Source: <http://www.tedspread.com>

\section{Figure 3.5b Model simulation*}

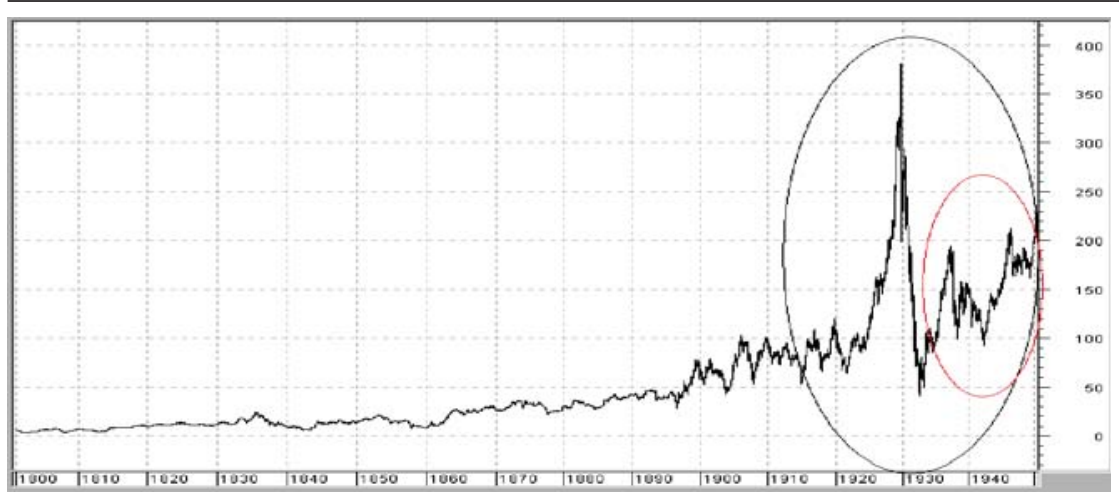

* The Dow-Jones Industrial Average Index (DJIA) during the great depression.

Source: Metastock

Now, we have a better understanding of why the derivative market might collapse on a large scale. When the option-trading mechanism is simple enough, Black could adjust the model parameters such as market volatility so that the theoretical solution could close on the empirical price. In a complicated over-the-counter derivative market without regulation, however, such as the credit default swap market, trading based on an oversimplified binomial-tree model would mislead the market without empirical calibration. This grand crisis has provided a striking example of how a linear model for a complex market can create such tremendous turmoil. Only new thinking in asset-pricing theory can prevent a similar crisis in the future. 


\section{Economic complexity of transaction costs and the selective mechanism of industrial organisation}

The US Administration has long realised the critical role of prudent financial regulation. Mainstream economists, however, still argue that the market can be self-regulating; following the Coase theory of transaction costs. Coase (1937) claimed that the foundation of the firm was the incentive to reduce transaction costs. Coase (1960) believed that social conflicts could be solved via bilateral exchange without interference from a third intermediary such as government or legal action. Coase (1988) assumed that the US financial market was an ideal model of the Coasian world of zero transaction costs. He seemingly ignored the fact that regulating the financial market greatly increased transaction costs. Coase (1979) raised the issue when he openly placed doubts on anti-bribery legislation for the media industry. $\mathrm{He}$ simply ignored the social costs that emerged when bribery and market manipulation generated system instability, which could potentially cost much more than regulation. The real aim of the Coase theory was to reject antitrust policy when he met the Chicago School (Kitch 1983). This study revives the old debate about antitrust policy from the new perspective of market instability and economic complexity. Coase is wrong simply because he ignored the issue of economic complexity (Chen 2007). Firm's driving force is value creation, not transaction costs reduction. Innovation creates both instability and complexity that are sources of increasing transaction costs in division of labour. Bilateral exchange cannot solve conflicting interests in pollution and market manipulation. Government regulation and people's participation is essential in maintaining orderly market and resolving social conflicts. Whether regulation is proper or not, it cannot be judged by transaction costs in the short-term, but by social effects in the long-term. Coase theory is another type of perpetual motion machine without heat (i.e. transaction costs) dissipation, which is against the second law of thermodynamics. The simple fact of global warming is a clear evidence of increasing energy consumption. China could avoid a financial crisis mainly because its policy is selectively open to constructive FDI, not speculative hot money. 


\section{The danger of the Friedman theory of exogenous money and the tripolar world of the Great Depression}

So far, the weak effect of expansionary monetary policy reminds us of the danger of the exogenous theory of business cycles, discussed previously. The current monetary policy adopted by mainstream economists is strongly influenced by Friedman's theory of exogenous money and his misleading explanation of the Great Depression (Friedman and Schwartz 1963). Friedman assumed monetary movement was exogenous, so central bankers' monetary policy had no historical and structural constraints. The discovery of monetary chaos challenged the monetarist theory of exogenous money but supported the Austrian theory of endogenous money (Chen 1988, 2005). Few economists, however, realised the danger of monetarist policy in dealing with an economic crisis such as the failure of the Washington Consensus, with crises in Latin America and East Asia and the transitional crisis in Eastern Europe and the former Soviet Union (Chen 2006, 2008).

Friedman claimed that expansionary monetary policy alone could have prevented the Great Depression, though there is no solid empirical evidence to support his theory. It would be very dangerous for Bernanke and other central bankers around the world to follow Friedman's theory in dealing with the current crisis.

On the contrary, we have solid evidence supporting the Austrian theory of endogenous money. In 1998, China had to confront severe deflation in the aftermath of the East Asian financial crisis. China managed to maintain sustained growth mainly through fiscal policy-manifest in large investments in infrastructure. So far, we already see that the effectiveness of monetary policy is highly constrained by historical policy and economic structure. When the business sector is heavily in debt, expansionary monetary policy can move only short-term interest rates and might be powerless to determine medium and long-term interest rates when investors feel uncertain about the economic outlook due to the danger of deep recession, possible inflation and currency depreciation. Since late 2008, major countries have rapidly adopted crisis policies such as monetary expansion, fiscal stimulus and enhancing regulation in the financial market, such as over executive pay and leverage restriction. From our observation, the US Administration has tried only to treat the symptoms rather than to cure the American disease, which is the huge 
power of the financial sector to crowd out the industrial sector. So far, we see no attempt by policymakers to break up monopolistic financial firms such as AIG and Citibank. Thinking strategically, we should prepare for the worst scenario and then work out the best solution.

Kindleberger (1986) has produced a highly relevant analysis that is helpful in understanding the current crisis. Friedman believed that the Great Depression was triggered by one simple event: the death of New York Federal Reserve Governor, Mr Strong, which left a vacuum in the Fed's monetary policy. Kindelberger pointed out that the global depression was caused by the collapse of globalisation based on British leadership. The three world powers after World War I- the United Kingdom, the United States and France - were kicking the ball among themselves and eventually provoked a collapse in the whole global system. We have a similar situation today, since the United States has lost its automatic world leadership via excessive military expansion and excessive consumption. The world order has changed since the 1980s; unless the United States, Europe and China coordinate their efforts, we could face a situation worse than the Great Depression in the 1930s.

What is the worst situation that might result from this grand crisis? Japan's stock market and real estate crisis of the 1990s lasted more than a decade. US President Roosevelt's 'New Deal', including Keynesian policy in fiscal stimulus and welfare policy, did not end the Great Depression, which lasted 11 years until it ended with World War II. There may be little chance of World War III among the major nuclear powers; however, the next wave of government default could destabilise small countries (such as happened in the recent Baltic crises), worsen existing wars in the Middle East and intensify regional and ethnic conflicts in South Asia and Africa. The possibility of a regional nuclear war in the Middle East and South or North-East Asia should not be fully discounted.

The best-case scenario is that current globalisation can be stabilised. This is possible only if trust in security matters and financial coordination can be consolidated among the major military and economic powers, including the United States, the European Union, China, Russia and Japan. The Cold War did not turn into a 'hot war' since the Yalta bipolar structure was stable during the Cold War era. Since the Soviet Union dissolved, the unipolar structure based on US dominance is significantly unstable in a world of disequilibrium with increasing disparity between rich and poor countries. 


\section{The American disease and the China puzzle}

Before discussing China's role, we need to understand the world today from an evolutionary perspective. Bernanke once suggested that the US imbalance was rooted not in excessive consumption but in China's excess saving. I have a different view on this. The United States is much more powerful than China and the other Asian economies combined. Its financial power still dominates the international financial order - as we already know from the foregoing discussion.

The United States' trouble in the financial markets began with former President Ronald Reagan's contradictory economic policies in the 1980s. On the one hand, Reagan launched a tremendous military expansion; on the other hand, he provided substantial tax cuts and deregulated the financial sector. Growing public debt financed the budget deficit that resulted, which drove up interest rates and the dollar and ruined the competitiveness of the US manufacturing industry. As we know, the response to this was outsourcing - first to Japan and then to East Asia. The United States pushed Japan to appreciate the yen, but that did not solve its trade deficit. Instead, it threw the manufacturing industry out of Japan and to the 'Asian tigers' and mainland China. Ever since, the United States has been putting pressure on the Chinese Government to appreciate its currency, but without success.

The United States' fundamental problem is that the financial sector has replaced the industrial sector as the driver of its economy. You cannot cure that disease by playing currency or monetary games. Since the 1970s, no matter how the exchange rate has fluctuated, the United States has had a persistent trade deficit, while Germany and Japan have had a persistent trade surplus. This has nothing to do with exchange rates, but with US policy. The United States has advanced technology and abundant resources, but continues to waste immense resources on military spending and financial speculation. What is needed is a fundamental change in its policy framework.

As for China, of course it has suffered from US foreign policy, but it has also benefited. During the East Asian financial crisis, China followed the United States' recommendation that it should not devalue its currency. Before and during that crisis, mainstream American economists had one single policy recommendation for Latin America, Hong Kong and China: dollarisation, dollarisation and dollarisation! Remember that most Chinese reformers tried very hard to learn about the market economy from the US 
textbook. They all considered US Treasury Bonds a risk-free investment compared with risky stocks and corporate bonds. The Chinese Government therefore decided to target China's exchange rate with the dollar and buy US Treasury securities. This was thought to be the best way to preserve the value of Chinese savings - or at least a much better way than to invest them in China's own enterprises. Once China chose that road, however, US Treasuries turned out to be a trap. In such a situation, China had fewer options than Japan and European countries in the currency game, because of the asymmetrical policy adopted by the United States. When the dollar goes down, Japanese or Europeans can buy US assets, but Chinese cannotblocked as they are by the United States' national security policy. At the same time, American and other foreign banks and firms are invited to be strategic partners with China's state-owned firms for improving China's competitiveness. Does the United States think that China is blind and will sell her security interests to US firms?

I would still claim that this asymmetrical trade policy has in fact done more good for China than for the United States in the changing world balance. US administrations have repeatedly used political pressure in exchange rate policy. It did not resolve the US deficit problem, but it did accelerate the economic integration of East Asia. How did that happen? If world trade were free and based on rules of symmetry, China would be buying much more US technology than it really does. Since the United States does not allow exports of high-tech products to China, China can import only second-hand technology. The United States does, however, export high technology to Japan and other East Asian countries, and this preferential trade policy has created an arbitrage opportunity for these countries. It is not by accident that, since the 1980s, China has had a persistent trade deficit with Japan, then with South Korea and with South-East Asian countries. In fact, these deficits are quite comparable with China's trade surplus with the United States. What does this mean? It means that the United States has given away a huge trade opportunity to China's neighbours.

What, however, are the real results of this policy? After the East Asian financial crisis, all these countries realised that China was a more reliable partner in international trade than previously thought, since China did not devalue its currency despite the crisis. They also realised that their economies benefited greatly from China's rapid growth. So, geopolitically speaking, these countries went from being insecure neighbours to Chinese partners. South Korea, the larger of the Association of South-East Asian 
Nations (ASEAN) countries and Vietnam, in addition to Hong Kong and Taiwan, became increasingly integrated in the rapidly growing Chinese economy.

Today, East Asia is the third-largest economic zone in the world, with relatively stable exchange rates to the dollar, which also help to stabilise the US currency. If US policymakers realise that this can be the basis for closer economic cooperation, I would say that our future is bright. If, however, the United States considers this a challenge rather than an opportunity, it signals a troubling future.

This is the geopolitical heritage of the Reagan regime and the US imbalance. So far, the United States is still able to maintain its financial power in spite of increasing deficits. One critical factor in this is China's exchange rate policy. So far, both Chinese and Americans are happy about the past but worry about the future. Unlike her Asian partners, China does not get any credit from US policymakers. Perhaps the United States should think about how to win other people's trust rather than just other people's money.

We need to explain one of the 'China puzzles': why China has a much higher saving rate than industrialised countries - or why do poor countries end up subsidising the rich ones such as the United States? Some Western observers speculated that China's rapid growth was not based on technological progress and organisational innovation but on suppressing workers' wages and thus household consumption. They claim, therefore, that appreciation of the Chinese currency will not only solve the United States' problem of a persistent trade deficit, it will stimulate the consumption and welfare of the Chinese people. Is it that simple?

My observation is that China's high savings are the result of asymmetrical power in the credit market and marketing networks, since non-linear pricing is the main tool used by the multinational companies that dominate China's export market. More than half of China's exports are by foreign firms - and most export channels are controlled by multi-national firms such as Wal-Mart. Chinese companies and the Chinese Government has no pricing power in the international market. For any Chinese product sold in the United States, Chinese companies receive $2-5$ per cent of the sale value. As a result, China's domestic market is more open and more competitive than those of the United States, Japan or any other country in Asia and Europe. If we look, for instance, at China's car industry, we see that the market, unlike in the United States, is not dominated by the 
'big three'; there are more than 100 companies competing with each other. Their profit margins are very thin compared with their giant foreign competitors. In order to survive, they have to upgrade their technology through self-financed investment. Small and medium firms have little access to the stock or bond markets. The distorted financial market leads to a very high saving rate in Chinese firms.

Since China launched its reforms some 30 years ago, its annual growth rate in residential income and consumption has been about 7 and 6 per cent, respectively. China's high-saving puzzle cannot be explained by households; it is has to do with the behaviour of firms. If we look at the composition of China's immense bank deposits, the deposits of individuals represent some 50 per cent, with more than 30 per cent coming from firms. If there is so-called excess saving, China's domestic interest rate should be even lower than those in the United States. In fact, China's interest rate in the domestic market is much higher than that paid on US Treasuries. In rural industries, the grey-market interest rate is more than 20 per cent. Clearly, strong market competition leads to strong competition in investment in technological upgrading among all industries and firms. The Chinese Government has very limited means to cool investment since public investment is much smaller than private investment; in addition, regional governments have strong incentives to promote manufacturing industries.

I would guess that if the US Government adopts new antitrust laws and breaks up monopolistic firms, as it did with AT\&T, US industries will become more competitive and US households will behave more like Chinese households - investing in education and technology rather than in big houses and cars. In the end, you would see more balanced trade in the world market.

Bernanke points out China's high saving rate, rather than the low saving rate in the United States, as a possible source of financial instability. We might ask a more fundamental question about the driving force of growth: should it be consumption, investment, new technology or new industry?

US policymakers are talking loudly about economic stimulation to stimulate consumption. Economic indicators are often focused on the building of new houses and the sale of new cars, while there is soft talk about expanding the military industry. Can the United States recommend the same policy to developing countries without creating unequal competition in the global market? 
Let's assume that one country spends most of its income on consumption, while another country spends more on innovation. Which country do you think will win the international competition? That's a very simple question - no matter what natural resources and property rights we take into account. You don't need a grand theory; commonsense will do to answer this simple question.

\section{China's realistic role in a changing world order}

There is much debate about China's role in a changing world order-from the 'China threat' to 'G2' status. As a personal observation, China's success is based on a decentralised experiment in searching for a Chinese model of global competition. There are several features of the Chinese system that are different from mainstream economics based on the Anglo-Saxon model-so-called laissez-faire economics.

First, China has been a unified country since 200 BC-formed not by market forces but by political organisation based on a small-scale, self-sufficient economy. China has only 10 per cent arable land and has experienced frequent wars and natural disasters. Historically, there has been persistent demand for effective governments rather than small governments. China developed resource-saving but labour-consuming technology while the West developed labour-saving but resourceconsuming technology under different ecological conditions (Chen 1990, 1993). The Chinese model is therefore different from the Western model because there is a trade-off between stability and complexity (Chen 2005). This implies that developing countries should explore technologies appropriate to them and develop effective government to meet historical challenges. There is no universal recipe to fit a diversity of situations.

Second, China's shift of its development basis from inland to coastal areas was based on a strategic evaluation of the changing world order. The Korean War, the Vietnam War and the United States' policy of containment forced China to channel domestic savings into building up its defence industry and technological foundation. When US interest shifted to the Middle East, Deng Xiaoping's open-door policy seized the opportunity and developed the coastal economy, which became the engine of China's technological progress and export-led growth. China's competitiveness is not based on cheap labour, but on a cheap welfare system. Four-fifths of the population live on collectively owned land without paying expensive social security taxes. China's main strength lies in his human capital. A 
large number of engineers and scientists were trained in Mao's era. China's effort in transforming defence industry into civilian industry is more successful than the United States, East Europe and former Soviet Union. That is why China's open-door policy did not create a dependent economy; simply because China's domestic industry could rapidly learn and compete with multi-national company. Cheap labour alone never leads to takeoff in developing countries. In contrast, land and asset privatisation in Eastern Europe and the former Soviet Union led to a significant decline in agricultural and industrial output, a rapid increase in income inequality and a breakdown of the social welfare system. This process is visible again in the recent crisis in Baltic countries (Chen 2006).

Third, China is still a developing country with large regional disparities and tremendous population pressures under limited resources. Small and medium firms engage in the export market, mainly because market channels in the domestic market are far behind those in industrialised countries. It would be naive to demand that the Chinese currency ascend to reserve currency status, which could lead to premature liberalisation of the capital account. From international experience, Germany has more rigorous regulation of its financial market, so that German industry has firm support from the financial sector, while Japan wrongly accepted US advice in liberalising its financial market and lost a decade. China's policymakers should be careful in learning and experimenting in the international financial market.

We suggest that China could learn from other countries and play a constructive role in the global arena.

First, the European Union grew out of the European Coal and Steel Community in 1951, when France and Germany became partners instead of rivals. If China, Japan, South Korea and the ASEAN countries could build up a similar economic program - such as the joint development of offshore oil reserves - East Asia could integrate into an Asian union. Political wisdom with long-term vision is needed for Asian leaders in facing the current crisis. In Chinese, 'crisis' implies both danger and opportunity. The Japanese, South Korean and Chinese populations are ageing; therefore, there is diminishing chance of military conflict but increasing desire for economic cooperation. Even if US-led globalisation falls apart, East Asia could still maintain a stable and healthy economy. In doing so, other countries might join the East Asian community, including Australia, New Zealand, Russia, India and the Pacific United States, so that 
a better name in the future might be the 'Pacific Union', in parallel with the European Union and North America. The next phase of globalisation would then have a tripartite regional foundation that would be more promising than the existing US-led globalisation.

Second, the euro, yen and renminbi cannot yet displace the US dollar. The financial innovation of the 'euro dollar' market was created in 1957 by the Soviet Union and British banks in order to get around the controls of US financial power. Growing US deficits led to rapid expansion of the euro dollar market. In the current grand crisis, European banks have experienced heavy losses, caused by the US sub-prime crisis. This in turn has hurt South Korea, Brazil, Russia and other developing countries, as they have lost money on deposits in the euro dollar market. Chinese financial managers realised too late that the so-called 'risk-free' Treasury bonds was in fact risky assets, and they bought too many US Treasury bonds to 'preserve asset value'. China should cooperate with other Asian countries to develop an 'Asian dollar' market centred in Shanghai, since China could constructively utilise its excess foreign reserves. Currency and sovereign bond swaps can be integrated into the Asian dollar market, increasing its depth and sophistication over time. If the US Federal Reserve printed too much money, thereby destabilising the global economy, higher uncertainty would raise interest rates in both the euro and Asian dollar markets. Market forces would effectively discipline central bankers if their monetary policy was irresponsible or near-sighted. Goodwill alone is not a sufficient condition for a sound international order. International competition is a necessary condition for international stability.

Third, China's recent investment in foreign natural resources has caused a series of public relations problems since China's operation of state-owned enterprises (SOEs) is not compatible with Western laws. China should learn from the US model of land-grant universities and non-profit university endowment funds, rather than the Singaporean model of sovereign wealth funds. SOEs transformed into publicly listed, shareholder companies owned by university funds, pension funds, and so on, would greatly improve China's image abroad and its educational foundation at home. Currently, China's technological attainment depends heavily on foreign technology. China's higher education system is essentially a teaching rather than a research system. By dividing state assets among a dozen or so competitive 'land-grant' university endowment funds, China could build up a strong system of innovation by integrating research, education and production. Western media could easily understand the nature and 
objective of a Peking University Fund or Fudan University Fund along the lines, for example, of the Texas University Fund and Columbia University Fund as qualified investment institutions.

\section{Basic considerations in reforming the international financial market}

Based on the above discussion, there are some basic considerations for reforming the international financial market.

First, current economic and financial bureaucracies are heavily influenced by equilibrium economists and financial interests. It would be helpful to establish a non-governmental expert forum under the United Nations; their policy recommendations could be more constructive for discussions among world leaders.

Second, regulation and supervision should centre on an international competition or antitrust policy. The market shares of giant financial companies in the commodity market, currency market and some key financial sectors should be subject to an upper limit, such as 5 per cent. Trading volume should be monitored frequently and transactions above a certain threshold should be reported and regulated.

Third, a Tobin tax on currency exchanges is essential to protect small countries without large foreign reserves. Tobin tax receipts should be housed in a specific development fund for helping developing countries.

Fourth, each country has the sovereign right to match its exchange rate regime to its development stratagem. Its exchange rate can be used in SDR (Special Drawing Rights, a reserve assets created by IMF) calculations with gradual adjustment every five years or so. An economic council under the United Nations, which is responsible for coordinating major countries in stabilising their exchange rates, could regulate the International Monetary Fund (IMF). An orderly adjustment of exchange rates could be conducted every five years or so except in emergency situations.

Fifth, an overhaul of financial theory and financial regulation would speed up the academic debate about rethinking economic history and economic theory (Chen 2008). This conference on China's new place in a world in crisis is a small step in this direction. 


\section{References}

Black, F. and Scholes, M. 1973, 'The pricing of options and corporate liabilities', Journal of Political Economy, vol. 81, pp. 637-54.

Bloomberg.com, data source for exchange rate and interest rate.

Chen, P. 1988, 'Empirical and theoretical evidence of monetary chaos', System Dynamics Review, vol. 4, pp. 81-108.

1990, 'Needham's question and China's evolution - cases of nonequilibrium social transition', in G. Scott (ed.), Time Rhythms and Chaos in the New Dialogue with Nature, Iowa State University Press, University of South Dakota, Vermillion.

1993, 'China's challenge to economic orthodoxy: Asian reform as an evolutionary, self-organizing process', China Economic Review, vol. 4, pp. 137-42.

1996a, 'Trends, shocks, persistent cycles in evolving economy: business cycle measurement in time-frequency representation', in W. A. Barnett, A. P. Kirman and M. Salmon (eds), Non-linear Dynamics and Economics, Cambridge University Press, Cambridge, pp. 307-31.

1996b, 'A random walk or color chaos on the stock market? Timefrequency analysis of S\&P indexes', Studies in Non-linear Dynamics \& Econometrics, vol. 1, no. 2, pp. 87-103.

2002, 'Microfoundations of macroeconomic fluctuations and the laws of probability theory: the principle of large numbers vs. rational expectations arbitrage', Journal of Economic Behavior \& Organization, vol. 49, pp. 327-44.

2005, 'Evolutionary economic dynamics: persistent business cycles, disruptive technology, and the trade-off between stability and complexity', in K. Dopfer (ed.), The Evolutionary Foundations of Economics, Cambridge University Press, Cambridge, pp. 472-505.

2006, 'Market instability and economic complexity: theoretical lessons from transition experiments', in Y. Yao and L. Yueh (eds), Globalisation and Economic Growth in China, World Scientific, Singapore, pp. 35-58.

2007, 'Complexity of transaction costs and evolution of corporate governance', Kyoto Economic Review, vol. 76, no. 2, pp. 139-53. 
2008, 'Equilibrium illusion, economic complexity, and evolutionary foundation of economic analysis', Evolutionary and Institutional Economics Review, vol. 5, no. 1, pp. 81-127.

Coase, Ronald H. 1937, 'The Nature of the Firm,' Economica, 4(16), 386-405.

1960, 'The Problem of Social Cost,' Journal of Law and Economics, $3(1), 1-44$.

1979, 'Payola in radio and television broadcasting', Journal of Law and Economics, vol. 22, no. 2, pp. 269-328.

1988, The Firm, the Market, and the Law, University of Chicago Press, Chicago.

Cox, J., Rubinstein, M. and Ross, S. 1979, 'Option pricing: a simplified approach', Journal of Financial Economics, vol. 7, no. 3, pp. 229-63.

Duffie, D. 1999, 'Credit swap valuation', Financial Analysis Journal, vol. 55, no. 1, pp. 73-87.

Energy Information Administration, Data source of oil prices, $<$ http://www.eia.doe.gov>

Fama, E. F. 1970, 'Efficient capital markets: a review of theory and empirical work', Journal of Finance, vol. 25, pp. 384-433.

_ 1991, 'Efficient capital market II', Journal of Finance, vol. 46, no. 5, pp. 1575-617.

Friedman, M. 1953, 'The case for flexible exchange rates', in M. Friedman, Essays in Positive Economics, University of Chicago Press, Chicago.

Friedman, M. and Schwartz, A. J. 1963, Monetary History of United States, 1867-1960, Princeton University Press, Princeton, NJ.

Frisch, R. 1933, 'Propagation problems and impulse problems in dynamic economics', Economic Essays in Honour of Gustav Cassel, George Allen \& Unwin, London.

Gilligan, D. 2009, 'Did speculation fuel oil price swings', 60 Minutes, Dec.1, 2009, CBS Television, <http://www.cwpma.org/Template.php?$\mathrm{p}=$ HomeNewsPopup \&-d=News\&-r=52.0>.

Jia, J. C. and Chen, P. 2009, Exchange rate resonance-observations based on deviations from interest rate parity, CCER Working Paper, June, Peking University, Beijing. 
Kindleberger, C. P. 1986, The World in Depression, 1929-1939, Revised and enlarged edition, University of California Press, Berkeley.

Kitch, E. W. (ed.) 1983, 'The fire of truth: a remembrance of law and economics at Chicago, 1932-1970', Journal of Law \& Economics, vol. 26, no. 1, pp. 163-234.

Li, H. J. 2002, Which type of stochastic processes could better address the issue of microfoundations of macro fluctuations? Thesis, Mathematics School, Peking University, Beijing.

Lucas, R. E., jr, 1972, 'Expectations and the neutrality of money', Journal of Economic Theory, vol. 4, pp. 103-24.

Schrödinger, E. 1948, What is Life? Cambridge University Press, Cambridge.

Schumpeter, J. A. 1939, Business Cycles: A theoretical, historical, and statistical analysis of the capitalist process, McGraw-Hill, New York.

Tang, Y. N. and Chen, P. 2009, The trend collapses and the premium of turbulence: the premium of collective behavior and the dynamics of financial crisis, March, CNPE Working Paper, Fudan University, Shanghai.

U.S. Bureau of Census, Data source of household numbers and firm numbers.

Zeng, W. and Chen, P. 2008, 'Volatility smile, relative deviation, and trading strategy - a general diffusion model for stock price movements based on non-linear birth-death process', [in Chinese], Economic Journal Quarterly, vol. 7, no. 4, Peking University, Beijing, pp. 1415-36.

\section{Acknowledgments}

This chapter was presented in various forms at several international meetings on the current economic crisis. The author thanks participants for stimulating discussions at the IRE \& EPS Conference on 'Looking for Solutions to the Crisis: The United States and the new international financial system,' New School University, New York, 14 November 2008; the IDEAs Conference on 'Re-Regulating Global Finance in the Light of the Global Crisis,' Tsinghua University, Beijing, 9-12 April 2009; the Shadow Gn Meeting, Luiss University, Rome, 14 May 2009; the IRE \& EPS meeting on 'Financial and Banking Crisis: Looking for solutions, ' Paris, 15-16 June, 2009. 